\title{
Popularność w grupie rówieśniczej osób z zaburzeniami masy ciała
}

\section{Currency of people with body weight disabilities in peer group}

\section{DARIA CHMIELEWSKA ${ }^{1}$}

1 Centrum Diagnostyczno-Lecznicze Barska we Włocławku

\section{Streszczenie}

Wstęp. Najczęstszymi zaburzeniami jakie występują u dzieci w wieku szkolnym są zaburzenia masy ciała. Zalicza się do nich nadwagę, otyłość, a także niedobór masy ciała. Oprócz powikłań somatycznych zaburzeń masy ciała dochodzi także do powikłań na tle psychicznym prowadząc do anoreksji, bulimii czy depresji. Głównym czynnikiem jest nietolerancja i odrzucenie przez grupę rówieśniczą, które negatywnie wpływa na rozwój i funkcjonowanie dzieci i młodzieży.

Cel. Celem pracy była ocena akceptacji osób z zaburzeniami masy ciała w grupie dzieci w wieku szkolnym.

Materiał i metody. Badania zostały przeprowadzone w grupie 100 dzieci w Szkole podstawowej. Udział w badaniach był dobrowolny i odbył się za zgodą rodziców dzieci. Badania polegały na wypełnieniu anonimowej ankiety zawierającej metryczkę i 16 pytań. Zaburzenia masy ciała zostały wyłaniane na podstawie wskaźnika BMI i wskaźnika Cole’a, a wszystkie dane zebrane były w arkuszu własnego autorstwa. W momencie przeprowadzenia badań respondenci biorący udział byli uczniami klas V-VII w przedziale wiekowym 11-14 lat. Dziewczęta stanowiły $51 \%$ badanej populacji, natomiast chłopcy pozostałe $49 \%$.

Wyniki. Według wskaźnika Cole’a zaburzenia masy ciała występowały u 62\% badanej populacji. Około 30\% respondentów prawidłowo określiło swoją masę ciała, a 36\% zauważyło problemy z zaburzeniami masy ciała u swoich rówieśników. Ponad 70\% dzieci z zaburzeniami masy ciała przyznało, że doznało braku akceptacji z powodu swojej masy ciała. Prawie 65\% dzieci będących świadkiem nietolerancji wobec swoich rówieśników zgłosiło ten fakt wychowawcą. 
Wnioski. Odsetek dzieci z zaburzeniami masy ciała sięga ponad 50\%. Dzieci w wieku szkolnym zauważają problemy z zaburzeniami masy ciała u siebie i swoich rówieśników. Dzieci w wieku szkolnym doświadczają braku akceptacji ze względu na zaburzenia masy ciała. Nauczyciele/opiekunowie odgrywają istotną role wobec uczniów nieakceptowanych w środowisku rówieśniczym.

Słowa kluczowe: zaburzenia masy ciała, popularność, grupa rówieśnicza, brak akceptacji

\section{Summary}

Introduction. Common disabilities of towards children at school age are body weight disabilities. We can rank to them a flesh, an obesity or body weight deficit. Except for somatic complications of body weight disabilities it also comes to mental complications that lead to anorexia, bulimia or depression. The main factors of that situation are intolerance and rejection from peers chich has a negative impast on development and functioning of youth and children.

Aim. The thesis object was to assess the acceptance of pe ople with body weight disabilities in group of children at school age.

Reference and methods. A hundred children from Primary School entered the research. The participation in research was voluntary and approved by parents. The children had to filled an anonymous questionnaire that had a sixteen questions and a metrics. BMI and Cole rate was the basis to emerged the body weight disabilities. The data were took in authorship worksheet. The respondents of research were students of V-VII class and had 11-14 years. It was 51\% of girls and $49 \%$ of boys.

Results. According to Cole rate $62 \%$ of researching children had body weight disabilities. Approximately $30 \%$ of respondents stated their body weight as right but $36 \%$ saw problems with body weight disabilities with their peers. Over $70 \%$ of children with body weight disabilities own that they met with Lack of acceptance. Almost $65 \%$ of children reported to educator that they were fitness of intolerance towards peers.

Conclusion. Proportion of children with body weight disabilities totals over $50 \%$. The children at school age notice the problems with body weight disabi- 
lities towards themselves and their peers. Children at school age experienced lack of acceptance because of their weight. Teachers loom large for unaccepted students.

Key wards: body weight disabilities, currency, peer group, non-acceptance

\section{Wstęp}

Rozwój człowieka dzieli się na kilka sfer, które są ze sobą ściśle powiązane. Zaburzenia jednej z nich dają nieprawidłowości w innej. Dojrzewanie płciowe jest jedną ze sfer, w której zachodzą największe zmiany w wyglądzie zewnętrznym, budowie ciała jak i w sferze psychicznej.

Najczęstszymi zaburzeniami jakie występują u dzieci w wieku szkolnym, a zarazem w wieku dojrzewania są zaburzenia masy ciała. Zalicza się do nich nadwagę, otyłość, a także niedobór masy ciała. Przyczyny zaburzeń masy ciała są różnorakie. Do najczęstszych przyczyn niedożywienia zalicza się: podłoże genetyczne, choroby układu oddechowego, pokarmowego, moczowego, krążenia, nerwowego, hormonalnego, nowotworowe, zakaźne, metaboliczne czy ubóstwo. Przyczynami nadmiaru masy ciała jest nieprawidłowa dieta, brak aktywności fizycznej, czynniki psychospołeczne, czynniki genetyczne i dziedziczne. Przyczynami zaburzeń masy ciała mogą być czynniki natury psychospołecznej. Często stres i depresja powodują ucieczkę w nadmierne objadanie się, a niska samoocena i brak akceptacji swojego wyglądu może być pierwszym krokiem do anoreksji czy bulimii.

Zarówno nadmiar, jak i niedobór masy ciała jest niebezpieczny dla dzieci i młodzieży. Zaburzenia masy ciała powodują szereg powikłań somatycznych, które niosą konsekwencje na dorosłe życie. Mało tego zaburzenia masy ciała prowadzą do pogorszenia jakości ich życia. Wiek szkolny jest często okresem buntu, dokonywania wyborów, ale też nauki życia w grupie. Przez nadmierną masę ciała lub jej niedobór, dzieci doświadczają braku akceptacji i są izolowane przez rówieśników. To właśnie zjawisko stygmatyzacji jest jednym z głównych problemów w środowisku szkolnym. 


\section{Cel}

Celem pracy była ocena akceptacji osób z zaburzeniami masy ciała w grupie dzieci w wieku szkolnym.

\section{Materiał i metody}

Badania przeprowadzone zostały w grupie 100 dzieci w wieku 1014 lat w Szkole podstawowej. Zaburzenia masy ciała wyłaniane były na podstawie oceny wskaźnika BMI i wskaźnika Cole’a. Ponad połowę badanych stanowiły dziewczęta - 51,0\%. Zdecydowana większość uczniów zamieszkiwała wieś - 91,0\%. Średnia wieku uczniów wyniosła - 12,2 lat. Odchylenie standardowe stanowiło ponad 9,6\% wartości średniej, co świadczy o nieznacznym zróżnicowaniu wieku. Nieznacznie wyższą średnią odnotowano w grupie chłopców - 12,3 lat, w grupie dziewczynek - 12,1 lat. Najliczniejszą grupę stanowili uczniowie w wieku 11 lat $-38,0 \%$ oraz 12 lat - 2,0\%, najmniej liczną w wieku 13 lat - 17,0\%. Współzależność pomiędzy dwiema zmiennymi, obliczono za pomocą współczynnik korelacji R Spearmana. Zastosowano również, nieparametryczny Test U Manna-Whitneya, do oceny różnic jednej cechy pomiędzy dwoma populacjami (grupami). 


\section{Wyniki}

Charakterystyka kliniczna badanej grupy

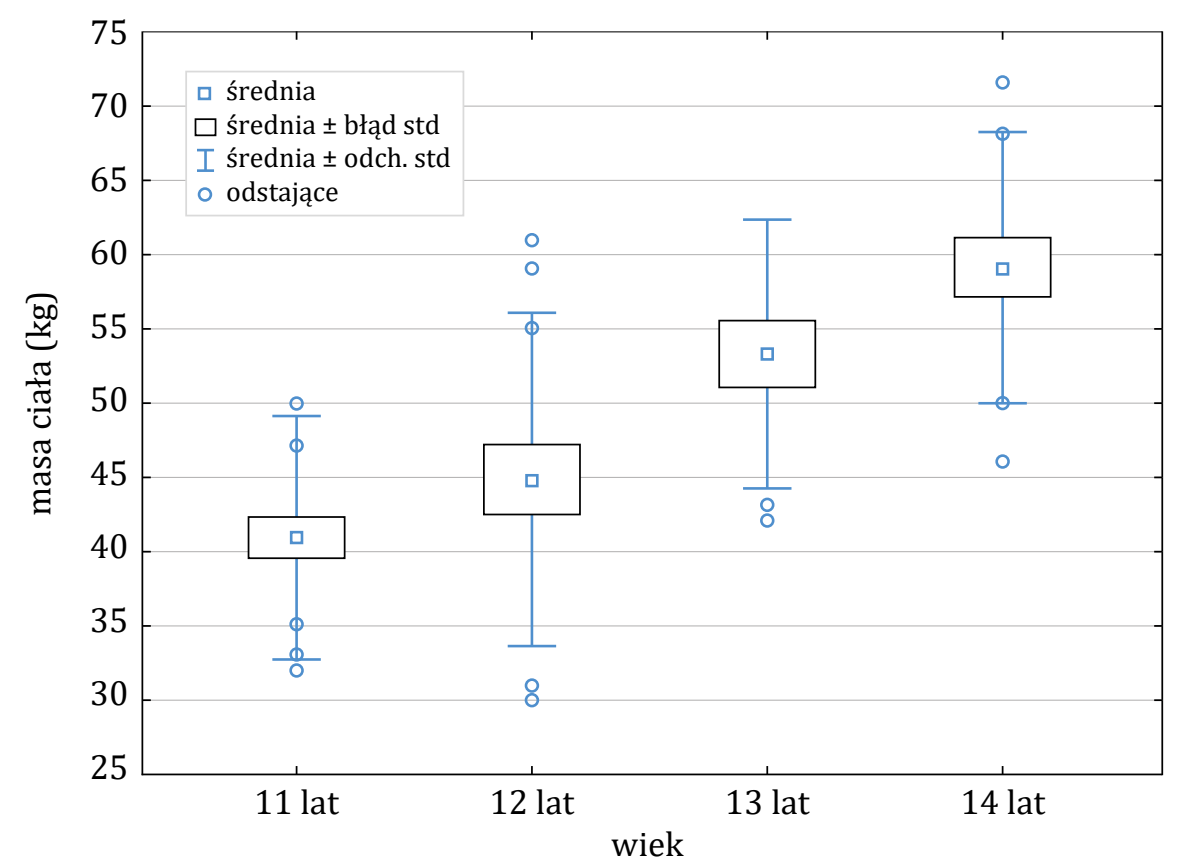

Rycina 1. Rozkład wyników średnich masy ciała w grupach wiekowych

Wynik średni masy ciała wyniósł - 47,85 kg. Odchylenie standardowe stanowiło ponad $24,5 \%$ wartości średniej, co świadczy o przeciętnym zróżnicowaniu wyników masy ciała. Najwyższy średni wynik odnotowano w grupie 14 lat - 59,1 kg oraz 13 lat - 53,2 kg. Najniższy w wieku 11 lat - 40,8 kg. Najwięcej uczniów uzyskało wynik 75-90 centyla $-23,0 \%$ oraz $50-75$ centyla $-14,0 \%$ i $25-50$ centyla - $11,0 \%$. Najmniej wynik 20-25 centyla oraz 90-75 centyla po 1,0\%. 
Tabela 1. Wyniki średnie wzrostu w grupach wiekowych

\begin{tabular}{|l|c|c|c|c|c|c|c|c|c|c|}
\hline Wiek & $\mathbf{N}$ & Średnia & SD & $\begin{array}{r}\text { Ufność } \\
\mathbf{- 9 5 , 0 \%}\end{array}$ & $\begin{array}{c}\text { Ufność } \\
\mathbf{+ 9 5 , 0} \%\end{array}$ & Min & maks & $\mathbf{Q 2 5}$ & $\begin{array}{c}\text { me- } \\
\text { diana }\end{array}$ & Q75 \\
\hline 11 lat & 38 & 144,5 & 10,308 & 141,14 & 147,91 & 120,0 & 168,0 & 136,0 & 145,0 & 152,0 \\
\hline 12 lat & 23 & 154,4 & 9,778 & 150,16 & 158,62 & 138,0 & 170,0 & 146,0 & 152,0 & 165,0 \\
\hline 13 lat & 17 & 163,5 & 7,151 & 159,85 & 167,21 & 151,0 & 175,0 & 157,0 & 165,0 & 170,0 \\
\hline 14 lat & 22 & 168,5 & 7,836 & 165,07 & 172,02 & 152,0 & 183,0 & 164,0 & 168,5 & 172,0 \\
\hline Razem & 100 & 155,3 & 13,327 & 152,67 & 157,95 & 120,0 & 183,0 & 145,0 & 156,0 & 165,0 \\
\hline
\end{tabular}

Wynik średni wzrostu wyniósł - 155,3 cm. Odchylenie standardowe stanowiło ponad 8,5\% wartości średniej, co świadczy o nieznacznym zróżnicowaniu wyników wzrostu. Najwyższy średni wynik odnotowano w grupie 14 lat -168,5 cm oraz 13 lat - 163,5 cm. Najniższy w wieku 11 lat - 144,5 cm. Najwięcej uczniów uzyskało wynik 25-50 centyla - 14,0\% oraz 50-75 centyla - 13,0\% i 75-90 centyla - 11,0\%. Najmniej wynik 10 centyla - 1,0\%. 


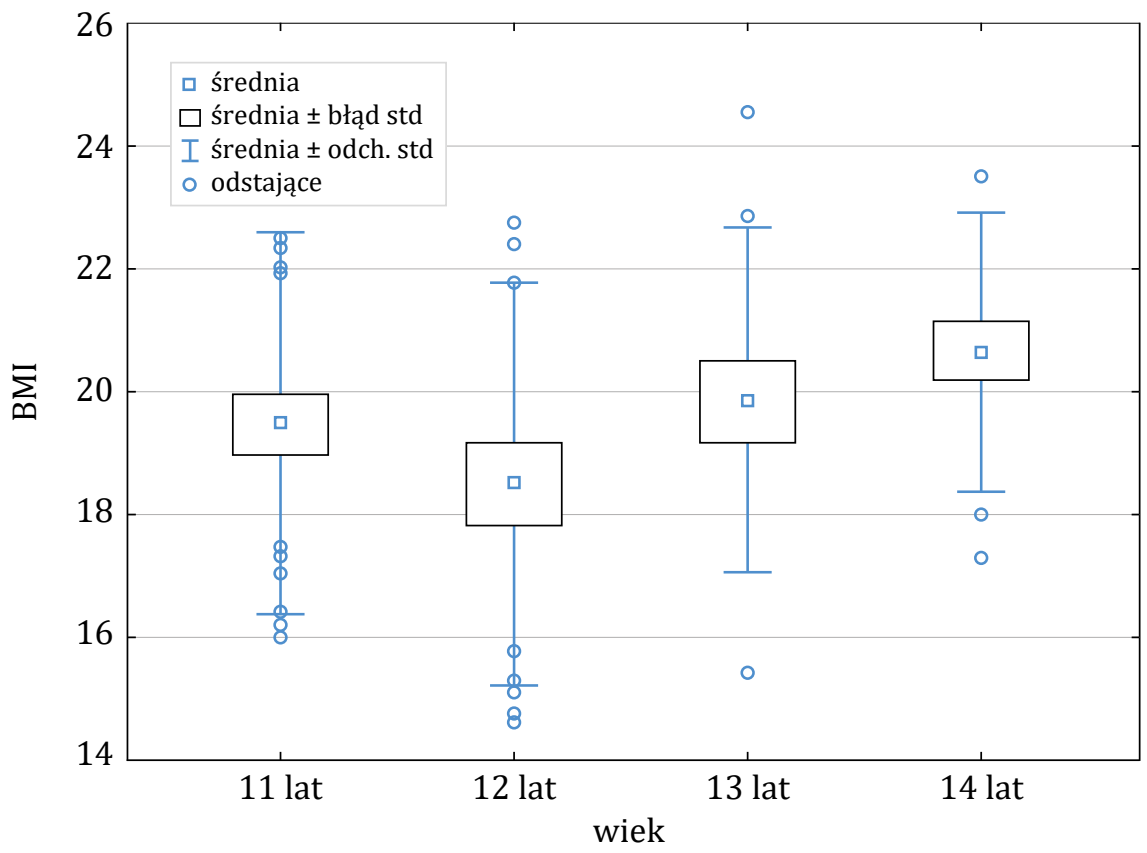

Rycina 2. Rozkład wyników średnich BMI w grupach wiekowych

Wynik średni BMI wyniósł - 19,59 punktu. Odchylenie standardowe stanowiło ponad 15,1\% wartości średniej, co świadczy o nieznacznym zróżnicowaniu wyników BMI. Najwyższy średni wynik odnotowano w grupie 14 lat - 20,66 punktu oraz 13 lat - 9,87 punktu. Najniższy w wieku 12 lat - 18,51 punktu. Najwięcej uczniów uzyskało wynik 5085 centyla - 35,0\% oraz 8597 centyla $-16,0 \%$. Najmniej wynik 3, 15 centyla po $3,0 \%$ oraz 50 centyla $-2,0 \%$. 


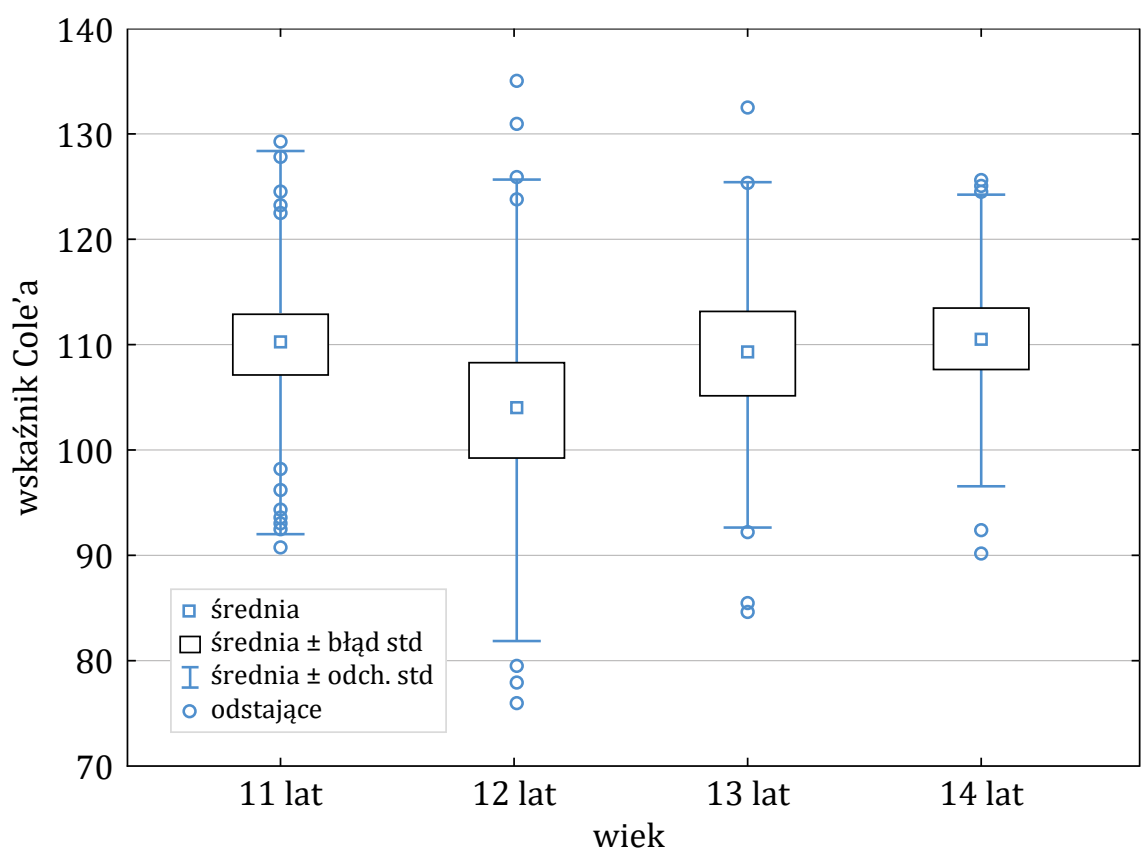

Rycina 3. Rozkład wyników średnich wskaźnika Cole’a w grupach wiekowych

Wynik średni wskaźnika Cole`a wyniósł - 108,38 punktu. Odchylenie standardowe stanowiło ponad 16,5\% wartości średniej, co świadczy o nieznacznym zróżnicowaniu wyników. Najwyższy średni wynik odnotowano w grupie 14 lat - 110,23 punktu oraz 11 lat - 109,95 punktu. Najniższy w wieku 12 lat - 103,56 punktu. 


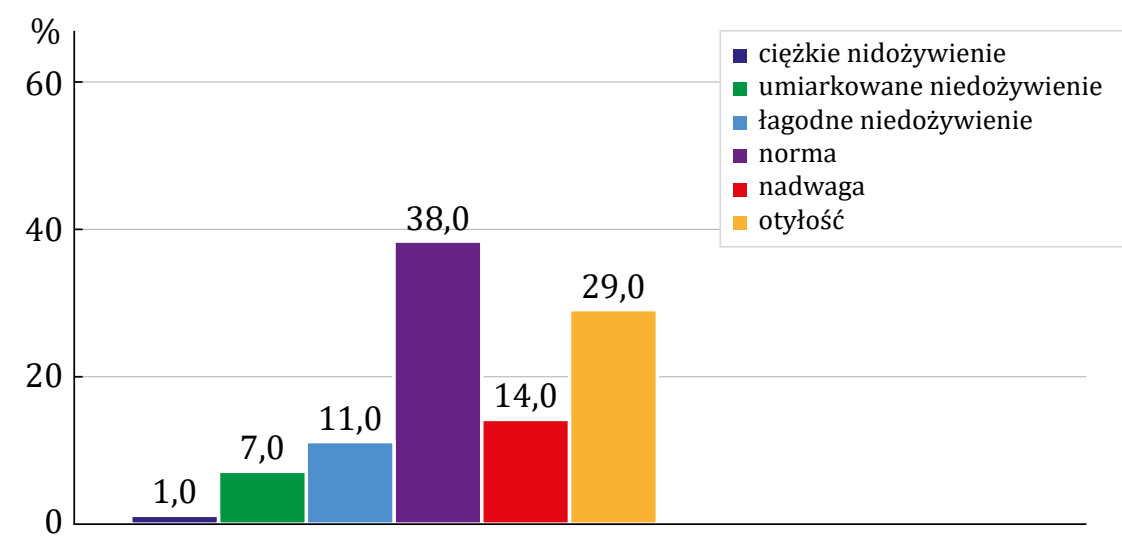

Rycina 4. Rozkład klasyfikacji McLarena

Najliczniejszą grupę stanowili badani z normą - 38,0\% oraz otyłością, najmniej liczną z ciężkim niedożywieniem - 1,0\%. Do dalszej analizy, osoba ta zakwalifikowana zostanie do grupy umiarkowanego niedożywienia.

Ze względu na poziom istotności ( $p>0,05)$, nie odnotowano istotnej statystycznie różnicy pomiędzy grupami płci, dotyczącej wyników klasyfikacji McLarena. Wiek badanych uczniów, nie pozostawał w istotnej statystycznie korelacji z wynikami klasyfikacji McLarena $(p>0,05)$.

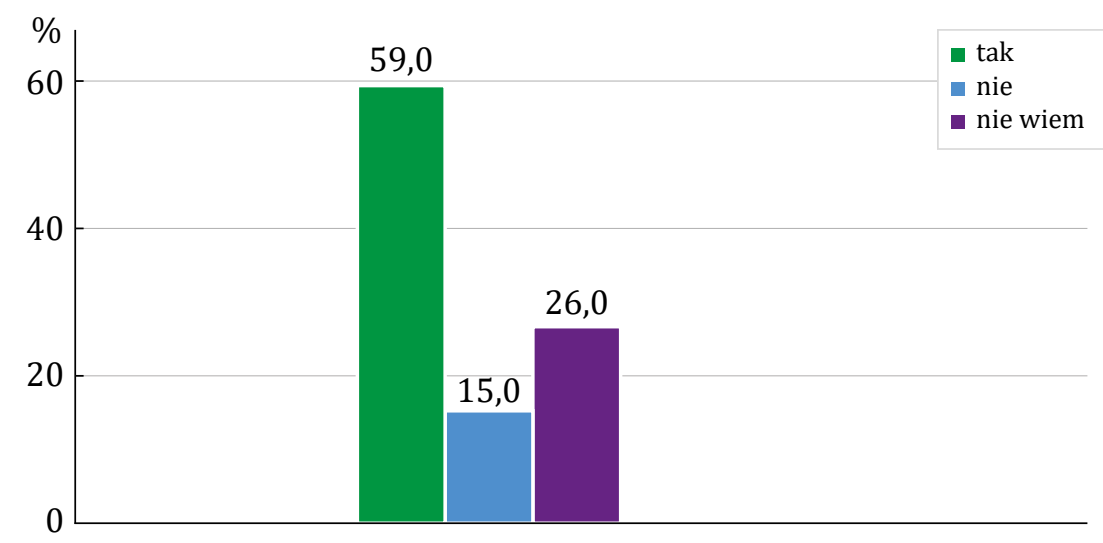

Rycina 5. Rozkład samooceny prawidłowości własnej masy ciał 
Najliczniejszą grupę stanowili uczniowie, którzy stwierdzili, że ich masa ciała jest prawidłowa - 59,0\%, najmniej liczną będący odmiennego zdania - 15,0\%.

\section{Analiza zagadnień dotyczących tolerancji w badanej grupie}

Zdecydowana większość badanych wskazała, że posada grupę przyjaciół/ kolegów, z którymi spędza czas wolny na przerwie - 96,0\%.

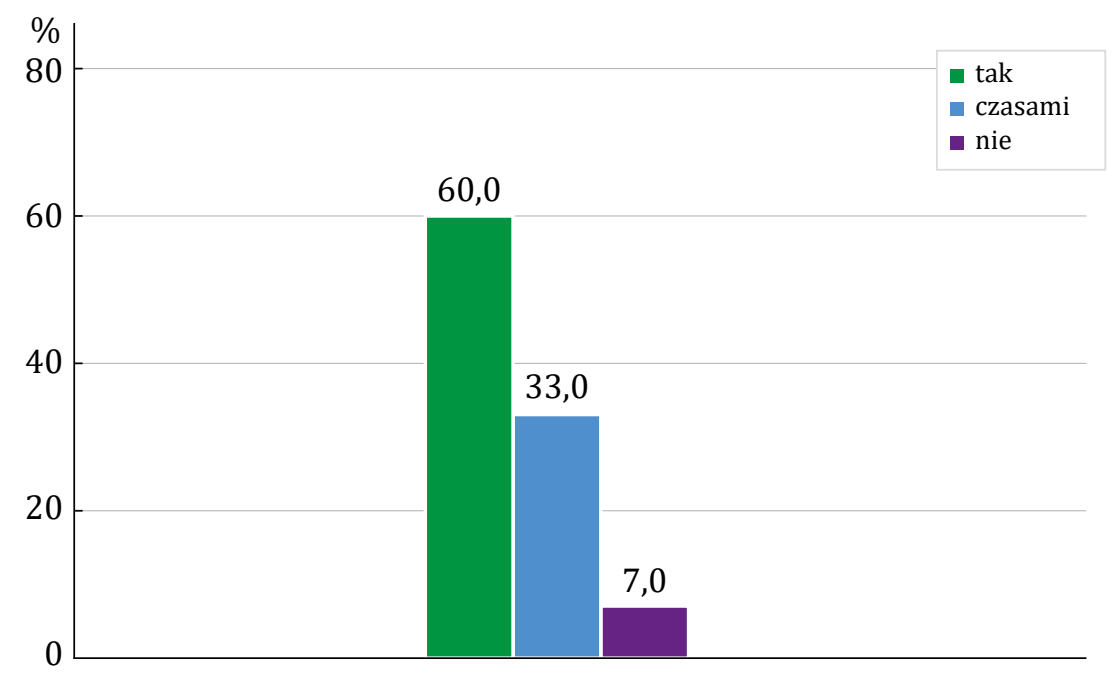

Rycina 6. Rozkład opinii, że inni uczniowie liczą się z ich zdaniem

Najwięcej uczniów stwierdziło, że inni uczniowie liczą się z ich zdaniem - 60,0\%. Najmniej wskazało, że nie - 7,0\%. 


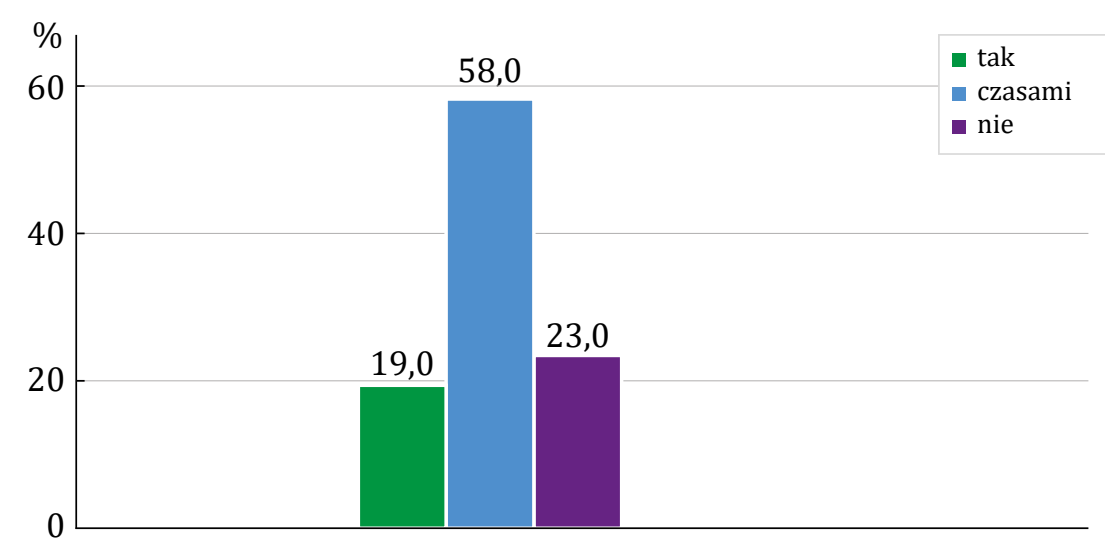

Rycina 7. Rozkład wywierania wpływu na postępowanie innych uczniów

Najwięcej uczniów stwierdziło, że wywierają czasami wpływ na postępowanie innych uczniów - 58,0\%. Najmniej wskazało, że tak 19,0\%. Większość uczniów wskazała, że cieszy się zaufaniem innych uczniów - 87,0\%. Większość wskazała, że nie doznała nigdy braku akceptacji z powodu swojej masy ciała $-71,0 \%$.

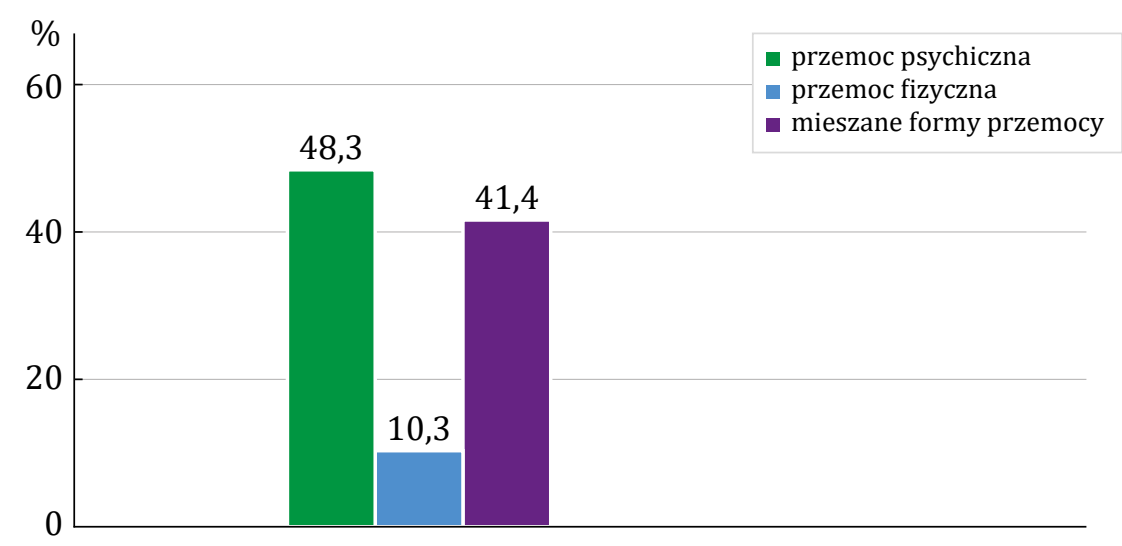

Rycina 8. Rozkład przejawów braku akceptacji 
Najwięcej młodzieży wskazało, że przejawem braku akceptacji był przemoc psychiczna - 14 osób (48,3\%), najmniej wskazało na przemoc fizyczną - 3 osoby (10,3\%).

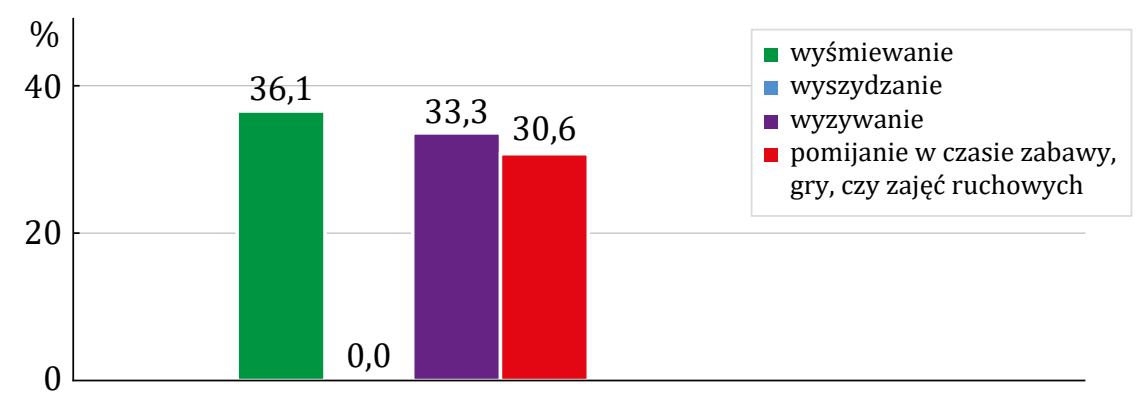

Rycina 9. Rozkład dominujących form przemocy psychicznej

Wymieniając dominujące formy przemocy psychicznej badani zaznaczali po kilka stwierdzeń. Łącznie od 29 osób odnotowano 36 odpowiedzi. Najwięcej uczniów wskazało na wyśmiewanie - 13 osób, co stanowiło $36,1 \%$ wszystkich zaznaczonych stwierdzeń. Najmniej wskazało na pomijanie podczas zabaw, gier, czy zajęć ruchowych - 11 osób $(30,6 \%)$. Na jedną formę przemocy psychicznej wskazały - 24 osoby, na dwie formy - 3 osoby, na trzy formy - 2 osoby.

Na pytanie o częstość występowania aktów braku akceptacji odpowiedzi udzieliło 51 uczniów. Najwięcej wskazało, że rzadziej niż 1-2 razy w tygodniu - 43 osoby (84,3\%), następnie 1-2 razy w tygodniu $11,8 \%$. Najmniej stwierdziło, że codziennie - 2 osoby $(3,9 \%)$. 


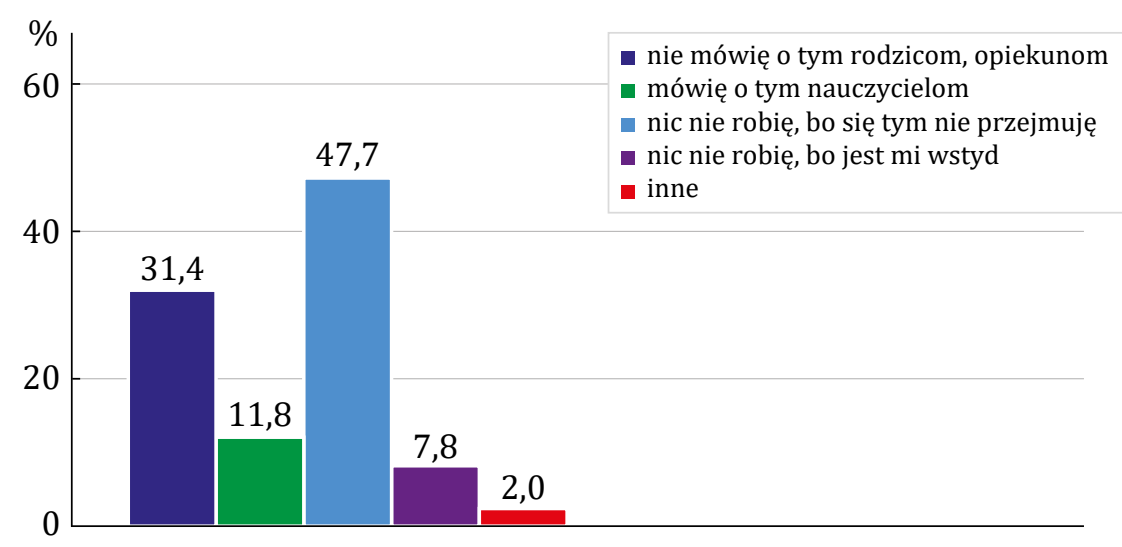

Rycina 10. Postępowania w przypadku doświadczenia braku akceptacji ze strony rówieśników

Najwięcej uczniów w przypadku doświadczania aktów braku akceptacji ze strony rówieśników nic nie robi, bo się tym nie przejmuję - 24 osoby $(47,1 \%)$ lub mówi o tym rodzicom/ opiekunom - 16 osób $(31,4 \%)$. Najmniej wskazało, że postępuje w „inny” sposób (wyzywam innych) - 1 osoba $(2,0 \%)$.

Najwięcej badanych stwierdziło, że nie zwróciło uwagi by koledzy, koleżanki mieli problem z zaburzeniami masy ciała - 64,0\%, aż 68,0\% uczniów wskazało, że nie było świadkiem aktu nietolerancji z powodu nadwagi i otyłości swoich kolegów i koleżanek. Większość uczniów wskazało, że nie była świadkiem aktu nietolerancji z powodu niedowagi swoich kolegów i koleżanek - 77,0\%. 


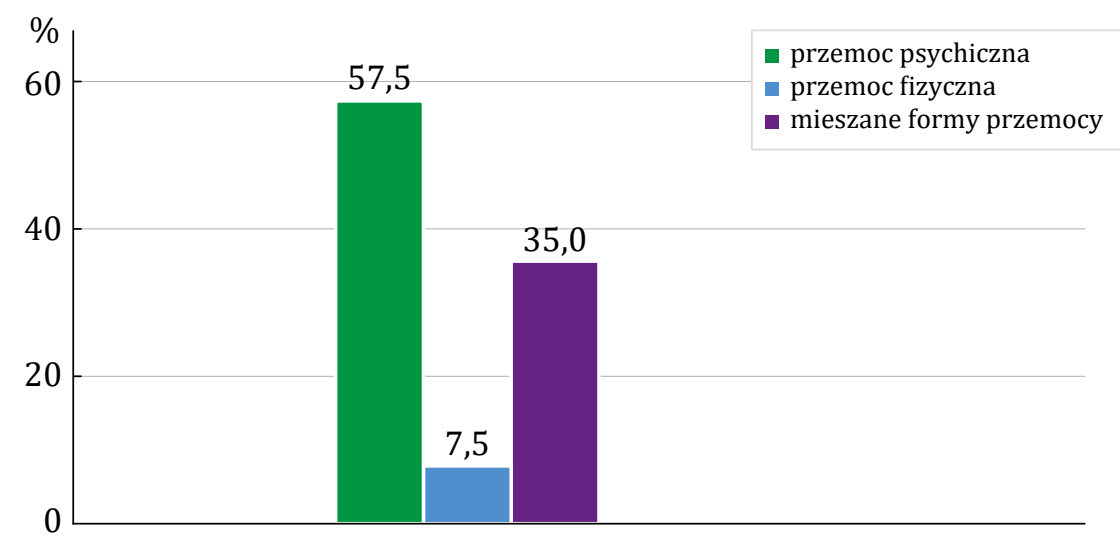

Rycina 11. Rozkład doświadczanych aktów przemocy przez koleżanki i kolegów

Najwięcej uczniów wskazało, że ich rówieśnicy doświadczają aktów przemocy psychicznej - 23 osoby (57,5\%), w najmniejszym stopniu przemocy fizycznej - 3 osoby $(7,5 \%)$.

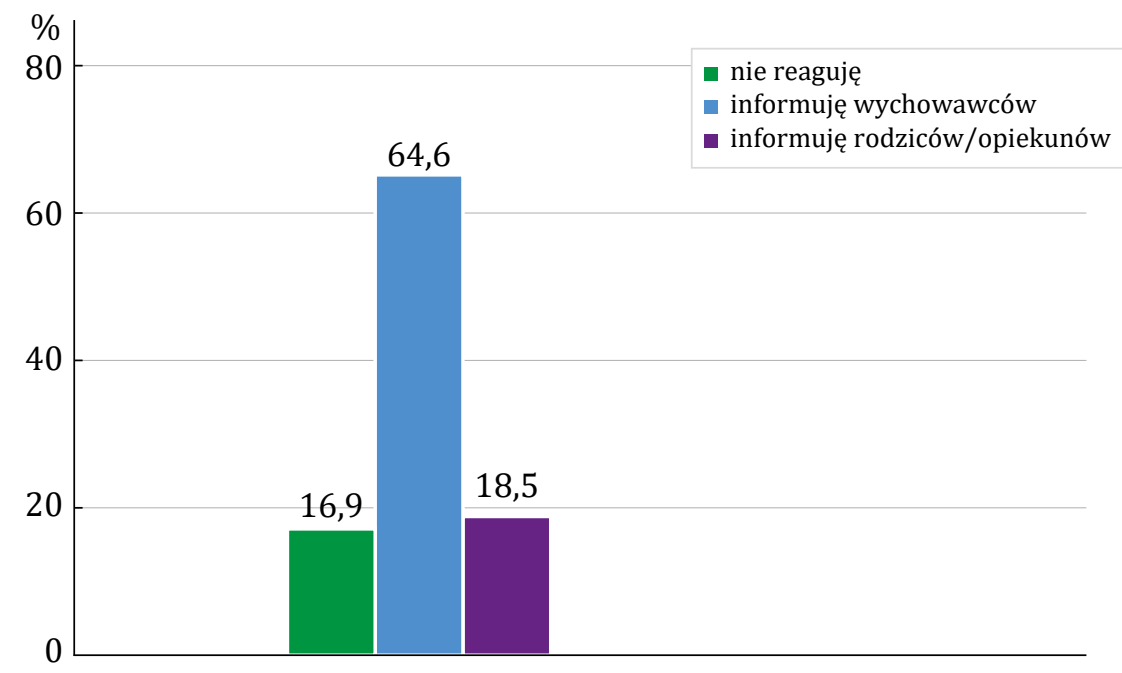

Rycina 12. Rozkład postępowania w przypadku bycia świadkiem aktu nietolerancji wobec swoich rówieśników 
W przypadku bycia świadkiem aktu nietolerancji, najwięcej uczniów wskazało, że informuje o tym wychowawców - 42 osoby $(64,6 \%)$, najmniej nie reaguje - 11 osób $(16,9 \%)$. Ze względu na poziom istotności $(\mathrm{p}<0,05)$, odnotowano istotną statystycznie różnicę pomiędzy dziewczętami i chłopcami, dotyczącą wyników zagadnienia: czy z Twoim zdaniem liczą się inni uczniowie.

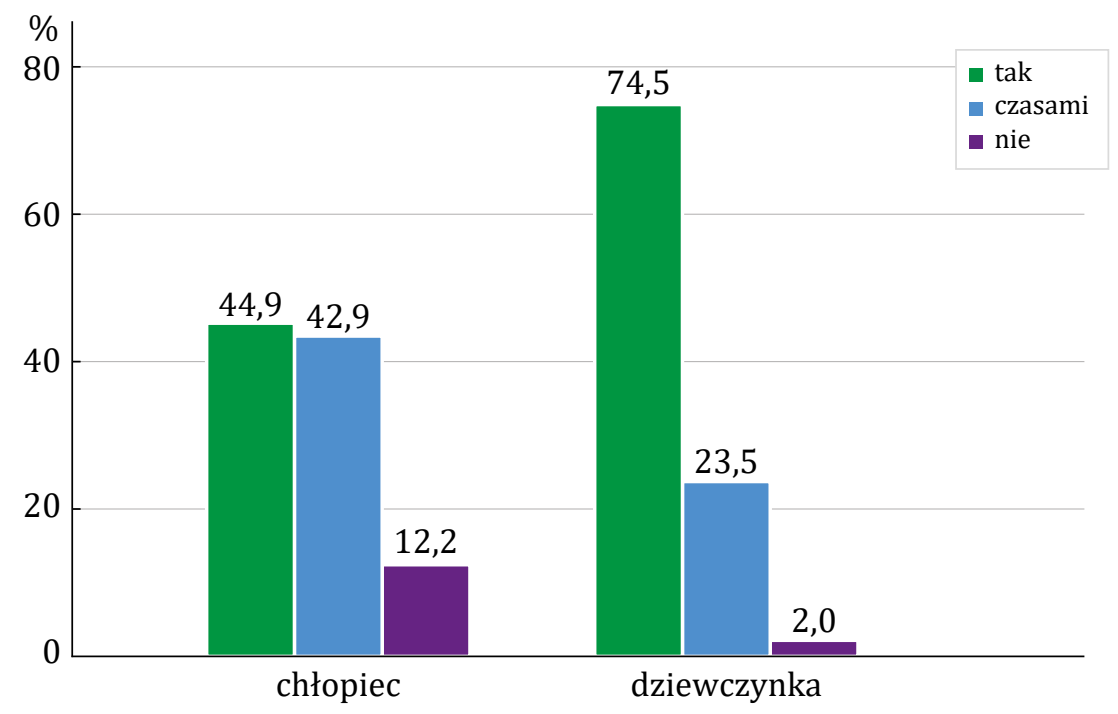

Rycina 13. Rozkład opinii, że inni uczniowie liczą się z ich zdaniem w grupach płci

W grupie chłopców najwięcej stwierdziło, że inni uczniowie liczą się z ich zdaniem - 22 osoby (44,9\%). Najmniej wskazało, że nie - 6 osób (12,2\%). W grupie dziewczyn większość wskazała, że tak - 38 osób (74,5\%), najmniej nie - 1 osoba $(2,0 \%)$.

Wiek badanych uczniów, pozostawał w istotnej statystycznie, niskiej korelacji z wynikami zagadnień: czy twoja masa ciała jest prawidłowa oraz byłeś świadkiem aktu nietolerancji z powodu nadwagi i otyłości wobec swoich kolegów i koleżanek $(\mathrm{p}<0,05)$. 


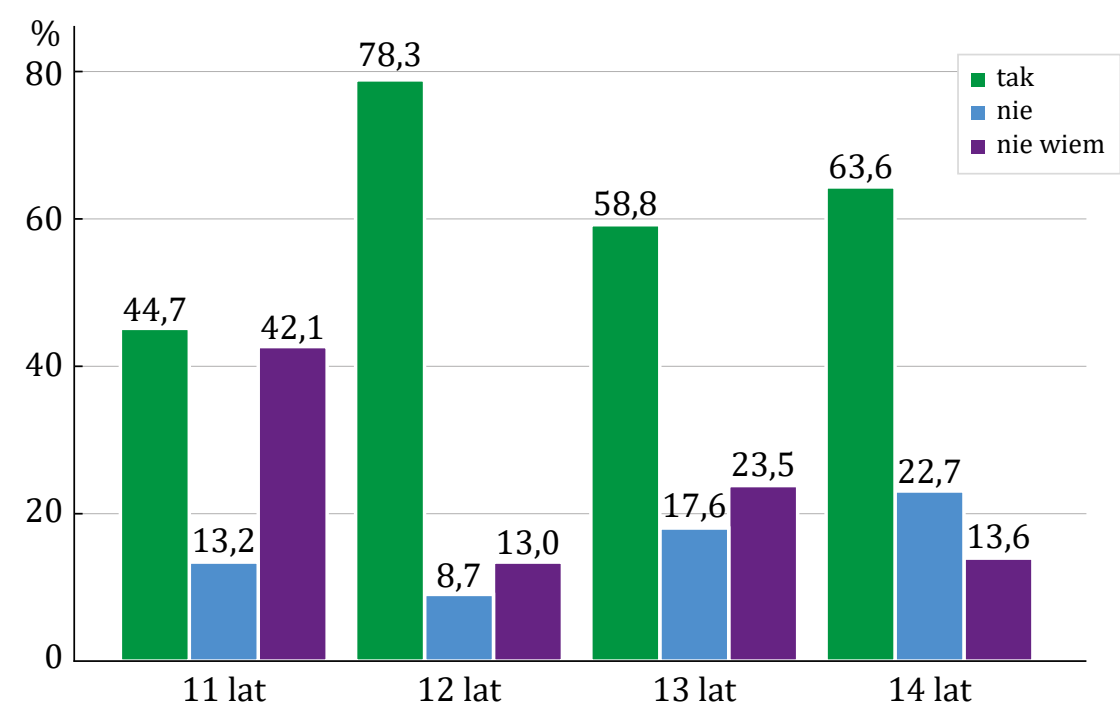

Rycina 14. Rozkład samooceny prawidłowości własnej masy ciała w grupach wiekowych

W największym stopniu przekonanie o prawidłowości swojej masy ciał wyrazili badani w wieku 12 lat - 18 osób (78,3\%) oraz 14 lat - 14 osób (63,6\%). W najmniejszym stopniu w wieku 11 lat - 17 osób $(44,7 \%)$. 


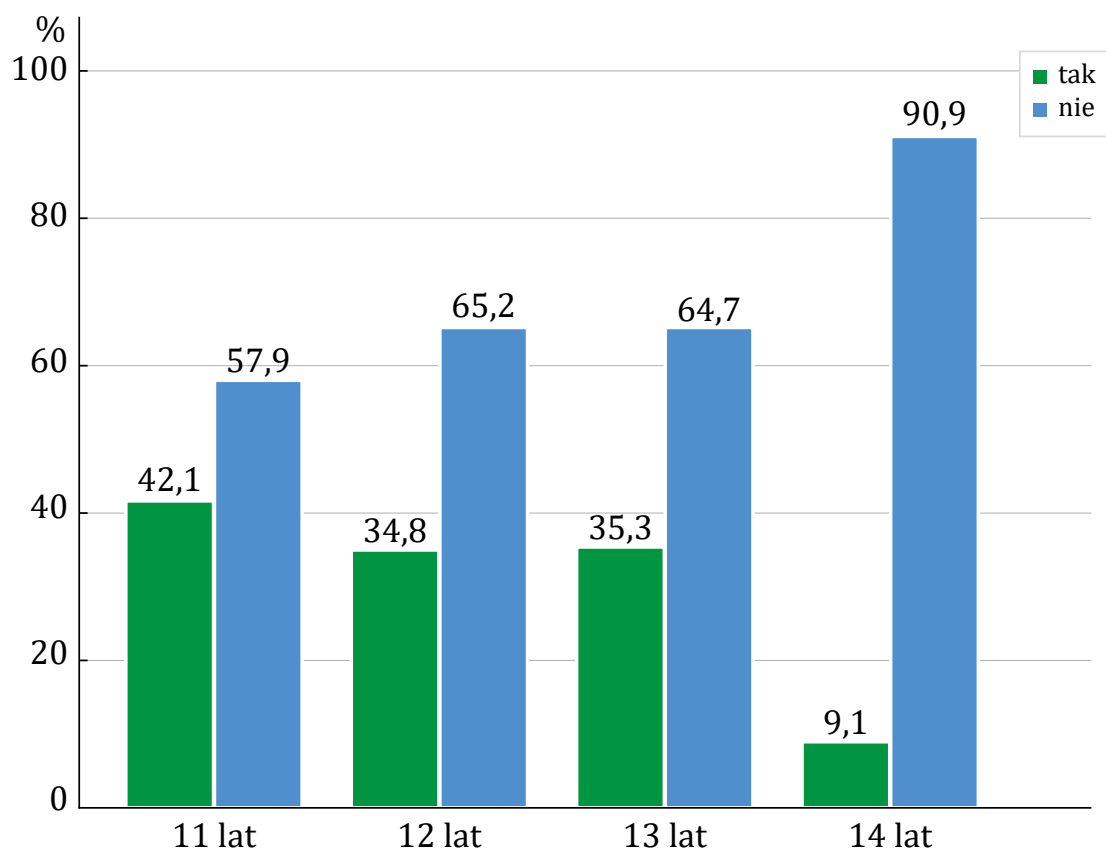

Rycina 15. Rozkład bycia świadkiem aktu nietolerancji z powodu nadwagi i otyłości wobec swoich kolegów i koleżanek w grupach wiekowych

W największym stopniu świadkami aktu nietolerancji z powodu nadwagi i otyłości wobec swoich kolegów i koleżanek byli uczniowie w wieku 11 lat - 16 osób $(4,1 \% 0$ oraz 13 lat - 6 osób (35,3\%). W najmniejszym stopniu w wieku 14 lat - 2 osoby $(9,1 \%)$.

Ze względu na poziom istotności $(\mathrm{p}<0,05)$, odnotowano istotne statystycznie różnice pomiędzy mieszkańcami miasta i wsi, dotyczące wyników zagadnień: czy z Twoim zdaniem liczą się inni uczniowie oraz czy cieszysz się zaufaniem innych kolegów. 


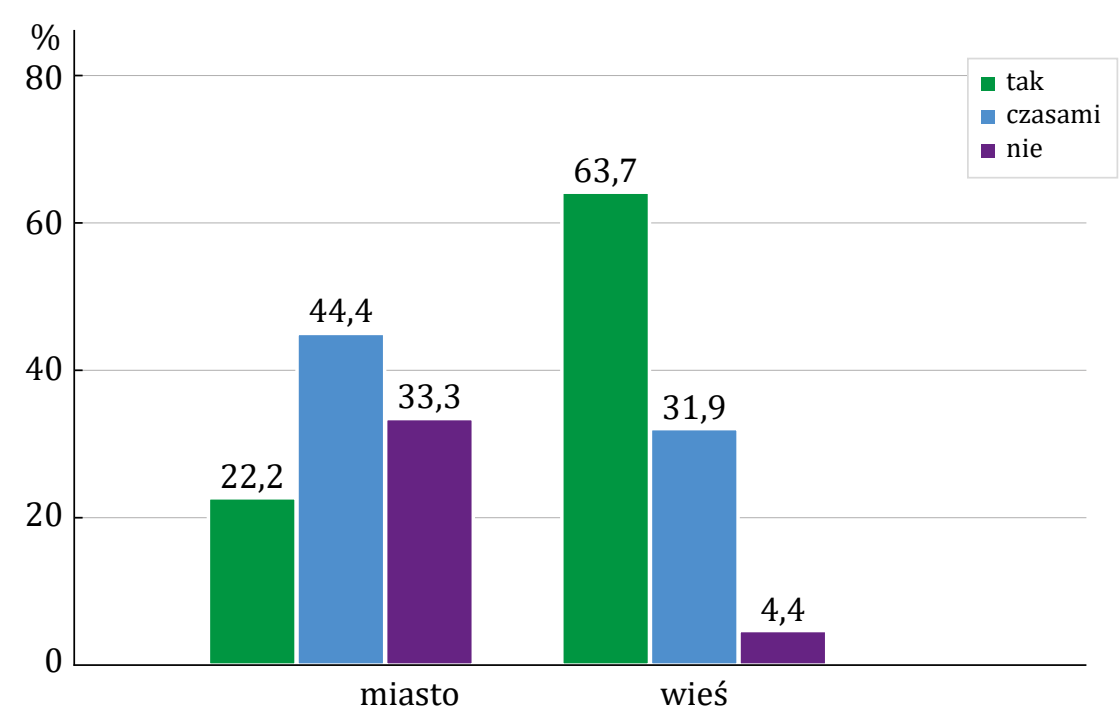

Rycina 16. Rozkład opinii, że uczniowie liczą się z ich zdaniem w grupach miejsca zamieszkania

W grupie mieszkańców miasta najwięcej stwierdziło, że inni uczniowie czasami liczą się z ich zdaniem - 4 osoby $(44,4 \%)$. Najmniej wskazało, że tak - 2 osoby (22,2\%). W grupie mieszkańców wsi większość wskazała, że tak - 58 osób (63,7\%), najmniej nie - 4 osoby (4,4\%). 


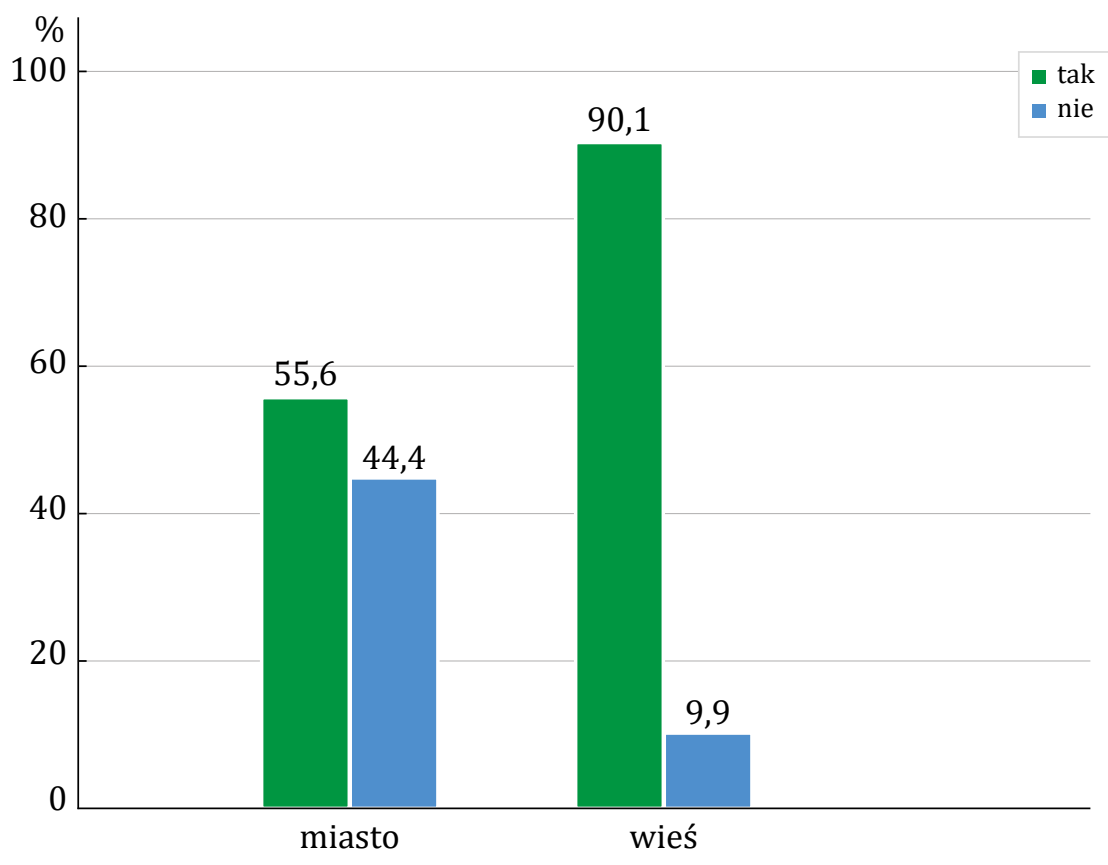

Rycina 17. Rozkład cieszenia się zaufaniem innych kolegów

W większym stopniu cieszyli się zaufaniem kolegów mieszkańcy wsi - 82 osoby $(90,1 \%)$. W grupie mieszkańców miasta -5 osób $(55,6 \%)$.

Wyniki klasyfikacji McLarena, pozostawały w istotnej statystycznie, średniej korelacji z wynikami zagadnień: czy twoja masa ciała jest prawidłowa oraz czy kiedykolwiek doznałeś braku akceptacji z powodu swojej masy ciała $(\mathrm{p}<0,05)$. 


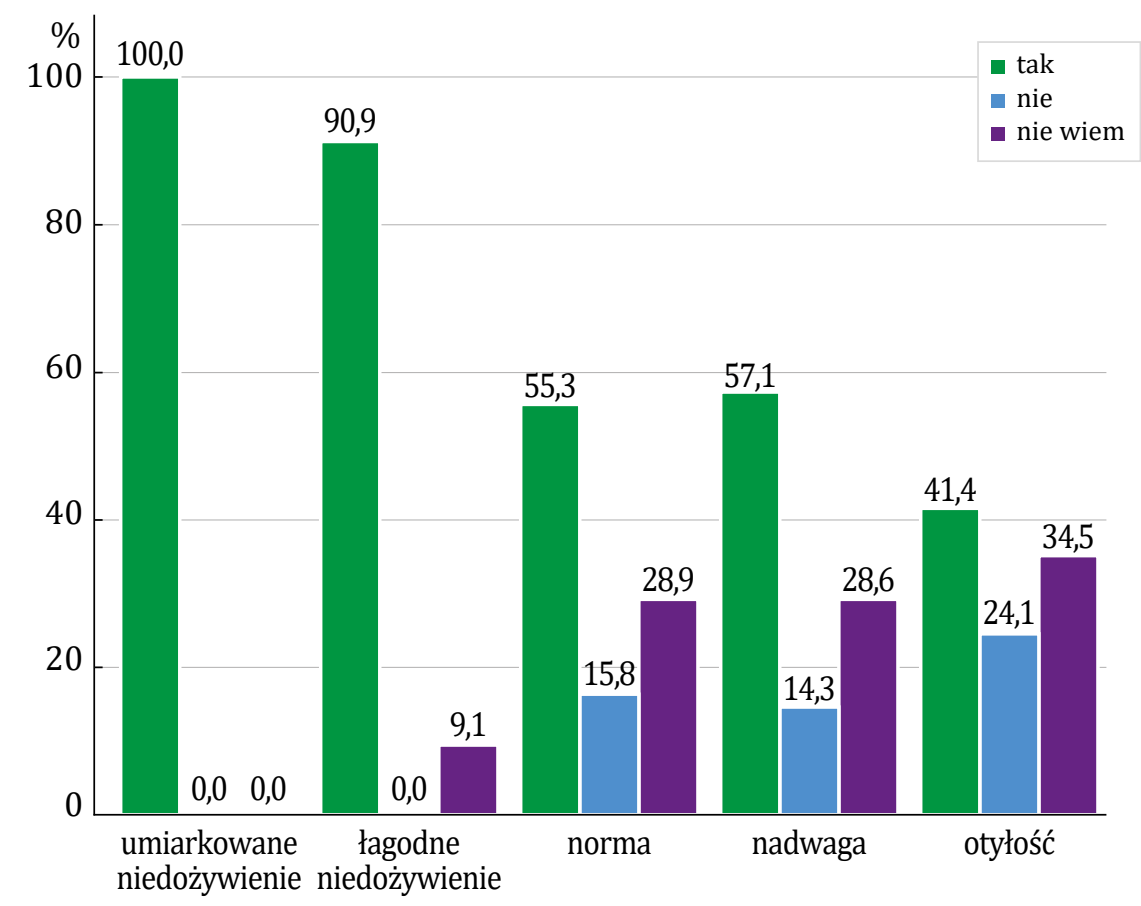

Rycina 18. Rozkład samooceny prawidłowości własnej masy ciała w grupach klasyfikacji McLarena

W największym stopniu przekonanie o prawidłowości swojej masy ciał wyrazili badani z umiarkowanym niedożywieniem - 8 osób (100\%) oraz łagodnym niedożywieniem - 10 osób $(90,9 \%)$ i nadwagą - 8 osób $(57,1 \%)$. W najmniejszym stopniu z otyłością - 12 osób (41,4\%). 


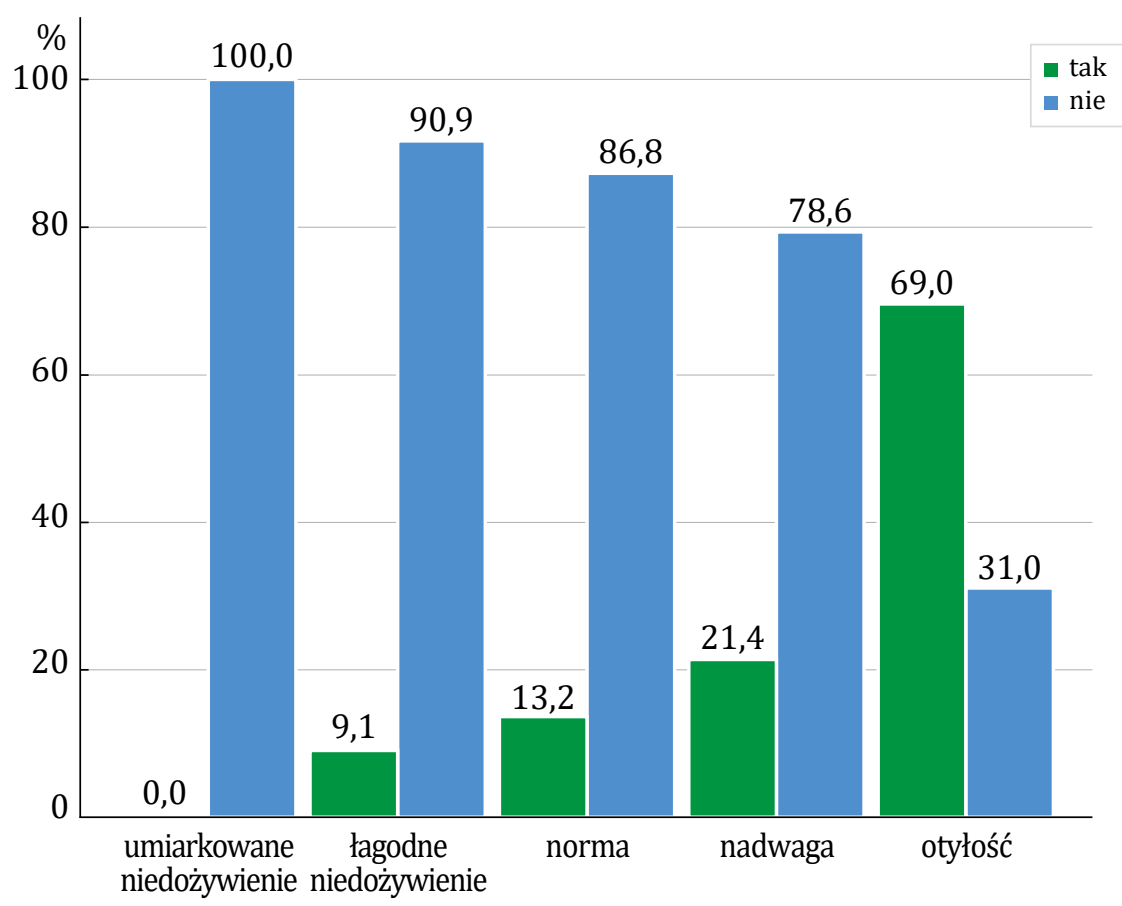

Rycina 19. Rozkład doznania kiedykolwiek braku akceptacji z powodu swojej masy ciała w grupach klasyfikacji McLarena

W największym stopniu na doznanie kiedykolwiek braku akceptacji z powodu swojej masy ciała wskazali badani z otyłością - 20 osób $(69,0 \%)$ oraz nadwagą - 3 osoby $(21,4 \%)$ i będący w normie -5 osób $(13,2 \%)$. W najmniejszym stopniu z łagodnym niedożywieniem - 1 osoba $(9,1 \%)$.

\section{Dyskusja}

Na stan odżywienia organizmu ma wpływ wiele czynników, między innymi czynniki genetyczne i środowiskowe, do których należą brak aktywności i złe nawyki żywieniowe, wpływ rówieśników i uleganie modzie. Nie należy zapominać o wpływie społeczno-ekonomicznym. Zauważalny jest wzrost liczby dzieci z otyłością w krajach wysoko roz- 
wijających się. Zaburzenia masy ciała, które występują u dzieci i młodzieży niosą za sobą szereg negatywnych konsekwencji. Otyłość i nadwaga negatywnie wpływa na zdrowie i rozwój dzieci powodując między innymi powikłania neurologiczne, endokrynologiczne, sercowo-naczyniowe, płucne, żołądkowo-jelitowe, nerkowe, mięśniowo-szkieletowe. Niedobór masy ciała powoduje obniżenie odporności i zmniejsza wydolność organizmu. Zaburzenia masy ciała niosą za sobą konsekwencje zdrowotne w dorosłym życiu. Oprócz powikłań somatycznych dochodzi także do powikłań na tle psychicznym, prowadząc do anoreksji, bulimii czy depresji. Wszystkie te powikłania natury psychicznej zaczynają się od jednego czynniki, którym jest nietolerancja i odrzucenie przez grupę rówieśniczą. Brak akceptowania przez grupę odmienności jest częstym zjawiskiem wśród dzieci i młodzieży. Brak akceptacji obniża samoocenę, powoduje przygnębienie, wycofanie się z funkcjonowania w grupie a nawet pogorszenie wyników w nauce.

Dlatego ważna jest nie tylko profilaktyka I fazy mające na celu zapobieganie, ale również profilaktyka II i III fazy [1].

Profilaktyka pierwszorzędowa obejmuje działania, które mają za zadanie nie dopuścić do wystąpienia pojawienia się choroby czy zaburzenia. Postępowanie pierwotne mające nie dopuścić do wystąpienia zaburzeń masy ciała uwzględnia:

- Promocje zdrowego stylu życia w rodzinie i tworzeniu zachowań sprzyjających zdrowiu,

- Edukację zdrowotną rodziców, dzieci i młodzieży co do odżywiania, aktywności fizycznej i świadomych wyborów konsumenckich,

- Wspieranie matek w utrzymaniu karmienia piersią do 6 miesięcy,

- Promocje zdrowia psychicznego mającej na celu minimalizacje stanów emocjonalnych prowadzących do „fałszywego głodu” czy „ucieczki w jedzenie” [2].

Profilaktyka drugorzędowa skierowana jest do grupy o zwiększonym ryzyku wystąpienia danej jednostki chorobowej. Stosowane testy przesiewowe służą do rozpoznania niezdiagnozowanych chorób czy 
wad. Dzięki temu można wyróżnić populacje osób z zaburzeniem i bez. Testy przesiewowe do oceny niedoboru i nadmiaru masy ciała wykonuje się w pierwszej dobie życia, 1-6 tygodniu, 2-6 miesiącu, 9 i 12 miesiącu, a także w wieku 2, 4, 6, 10,12, 16, 18/19 lat [3]. Test przesiewowy do wykrywania otyłości powinien być wykonywany również gdy podejrzewamy u dziecka zagrożenie otyłością. Test ten polega na wykonaniu pomiarów antropometrycznych, niezbędnych do obliczenia wskaźnika BMI. Profilaktyczne badania lekarskie inaczej „bilanse zdrowia” wykonywane u dzieci i młodzieży mają na celu dokonanie oceny rozwoju fizycznego, identyfikacje czynników zagrażających zdrowi dziecka, a także zaplanowanie koniecznych kroków diagnostycznych, korekcyjnych czy leczniczych [2].

Profilaktyka trzeciorzędowa dotyczy poradnictwa czynnego obejmujące dzieci i młodzież z problemami zdrowotnymi, szkolnymi, społecznymi, opiekę medyczną, psychologiczną, a także rehabilitacje. Profilaktyka III fazy ma na celu minimalizowane występujących już zaburzeń i zapobieganie dalszym skutkom, a także pomoc $\mathrm{w}$ radzeniu sobie $\mathrm{z}$ chorobą i zaakceptowanie stanu zdrowia, pomoc w utrzymaniu dobrej kondycji fizycznej i psychicznej, przeciwdziałanie izolacji społecznej [2].

W profilaktyce trzeciej fazy znaczącym elementem jest edukacja zdrowotna. Aby przynosiła ona pożądane efekty skierowana powinna być do pacjenta i jego otoczenia. Wyróżnić można:

- edukacja skierowana do dzieci i młodzieży ma na celu dostarczenie wiedzy dotyczącej oceny masy ciała, mobilizacji do pozbycia się nadwagi, utrzymania odpowiedniej masy ciała w kolejnych latach, zaakceptowanie własnej osoby i sposobów radzenia sobie ze stresem,

- edukacja skierowana do rodziców przygotowuje rodziców i opiekunów do bycia wsparciem dla otyłego dziecka, ale także dostarczenie wiedzy dotyczącej profilaktyki,

- edukacja skierowana do rówieśników ma na celu przede wszystkim uwrażliwienie osób nieotyłych na problemy osób z nadmiarem masy ciała i zapobieganie ich stygmatyzacji [2]. 
W badanej grupie zaburzenia masy ciała określano na podstawie BMI i wskaźnika Cole’a. Na podstawie BMI niedobór masy ciała stwierdzono u $17 \%$ badanych, nadwagę u $16 \%$ a otyłość u $11 \%$ - łącznie 44\% osób badanych miały zaburzenia masy ciała. Według wskaźnika Cole’a niedożywienie występowało u 19\%, nadwaga u 14\%, a otyłość u 29\% badanych. Łącznie zaburzenia masy ciała występowały u 62\% badanej populacji. Podobne wyniki zaobserwowano w badaniach Wolnickiej i wsp. niedobór masy ciała stwierdzono u 19,5\% badanych, nadwagę u 35,9\%, a otyłość u 10,6\% - łącznie $66 \%$ osób miało zaburzenia masy ciała [4]. Badania Kryski i wsp. wyłoniły 26,5\% osób z nadwagą i otyłością [5].

Dzieci w wieku szkolnym zauważają swoje problemy z zaburzeniami masy ciała. Z przeprowadzonych badań własnych wynika, że $42,1 \%$ dzieci w wieku 11 lat odpowiedziało, iż nie wie czy ich masa ciała jest prawidłowa, a w wieku 14 lat tylko 13,6\% dało taką odpowiedz. Wyniki ukazują także, że dzieci otyłe i z nadwagą częściej zauważają swój problem, a niżeli te z niedożywieniem. Dzieci z umiarkowanym niedożywieniem w $100 \%$ były przekonane o prawidłowości swojej masy ciała, a dzieci z otyłością tylko w 41,4\% (p<0,05).W przeprowadzonych badaniach $30 \%$ respondentów prawidłowo określiło swoją masę ciała w odniesieniu do klasyfikacji McLarena. Dzieci z prawidłową masą ciała, które twierdzą, że jest ona prawidłowa było 55,3\% , o nieprawidłowości swojej masy ciała przyznało $24,1 \%$ dzieci z otyłością i $14,3 \%$ z nadwagą. Ponadto $36 \%$ badanych zwróciło uwagę na zaburzenia masy ciała u swoich kolegów i koleżanek.

Z badań przeprowadzonych przez Krajewską-Siuda i wsp. 58,7\% dzieci prawidłowo określiło swoją masę ciała [6].

Z otrzymanych wyników zaobserwować można, iż dzieci z zaburzeniami masy ciała doświadczają braku akceptacji ze strony rówieśników. Aż $69 \%$ dzieci z otyłością i 21,4\% z nadwagą przyznało, że doznało braku akceptacji z powodu ich nadmiernej masy ciała. Także 9,1\% dzieci z niedowagą doświadczyło braku akceptacji. Częściej dzieci wolą zaakceptować kogoś za szczupłego, niż otyłego. Należy zwrócić uwagę, że 
$32 \%$ respondentów twierdzi, iż było świadkiem nietolerancji z powodu nawagi i otyłości wobec swoich kolegów i koleżanek oraz $23 \%$ z powodu niedowagi. $\mathrm{W}$ tym przypadku ważną zmienną był wiek, ponieważ $42,1 \%$ dzieci w wieku 11 lat było świadkami aktu nietolerancji, 34,8\% dzieci w wieku 12 lat , 35,3 w wieku 13 lat i 9,1\% dzieci w wieku 14 lat $(\mathrm{p}>0,05)$.

Badania Kryski i wsp. również potwierdzają tezę, że dzieci i młodzież w wieku szkolnym doznają braku akceptacji ze względu na swoją masę ciała. W badaniach tych aż $84,9 \%$ dzieci z nadmierną masą ciała przyznały, że doznały braku akceptacji ze strony rówieśników [5].

Wyniki badań własnych wskazują na to, iż uczniowie, którzy doznają braku akceptacji ze strony rówieśników szukają pomocy u opiekunów i nauczycieli. W przypadku braku akceptacji ze strony rówieśników $31,4 \%$ przyznało, że mówi o tym rodzicom i opiekunom, 11,8\% szuka pomocy u nauczycieli i wychowawców. Największa ilość respondentów bo aż $64,6 \%$ przyznało, że w przypadku bycia świadkiem aktu nietolerancji wobec rówieśników informuje o tym wychowawców a 18,5\% opiekunów. Należy zauważyć, że to właśnie nauczyciele odgrywają istotną rolę $\mathrm{w}$ rozwiązywaniu konfliktów w klasie. Na zadane pytanie „Jak wychowawcy rozwiązują konflikty w klasie związane z brakiem akceptacji" najwięcej odpowiedzi dotyczy tego, że nauczyciele rozmawiają o problemie na godzinach wychowawczych, przeprowadzają rozmowy i pogadanki o akceptacji, wyjaśniają konflikty, słuchają obu stron i próbują pomóc ale także zwracają uwagę na to co dzieje się na przerwach.

Na potwierdzenie tej tezy przywołać można badania Szulaczuk i wsp. w których nauczyciele zauważają problem odrzucenia rówieśniczego i dzięki prowadzeniu zajęć terapeutycznych i integracyjnych ułatwiają uczniom odrzuconym uczestnictwo w grupie klasowej [7].

W badanej populacji stwierdzono otyłość, nadwagę, niedowagę, ale także znajdowały się tam dzieci z wynikami mas ciała w granicach normy. Nie ulega wątpliwości, iż dzieci częściej zauważają problem nadwagi i otyłość, a także częściej doznają braku akceptacji z tego powodu. Przyczyną tego zjawiska może być częściej poruszany problem nadmia- 
ru masy ciała przez społeczeństwo, czy media niż problem niedożywienia. Wnioskować można, że dzieci starsze nie zwracają uwagi na akty nietolerancji wobec swoich rówieśników lub nie chcą tego przyznać. Pozytywnym aspektem jest fakt, iż większość dzieci nietolerowanych przez rówieśników, a także świadków nietolerancji, reaguje na problem i informuje o tym nauczycieli i opiekunów, dzięki czemu minimalizować można skutki braku akceptacji w grupie rówieśników.

\section{Wnioski}

1. Odsetek dzieci z zaburzeniami masy ciała sięga ponad $50 \%$.

2. Dzieci w wieku szkolnym zauważają problemy z zaburzeniami masy ciała u siebie i swoich rówieśników.

3. Dzieci w wieku szkolnym doświadczają braku akceptacji ze względu na zaburzenia masy ciała.

4. Nauczyciele/opiekunowie odgrywają istotną role wobec uczniów nieakceptowanych w środowisku rówieśniczym.

\section{Zalecenia dla praktyki pielęgniarskiej}

Na zapobieganie i przeciwdziałanie zaburzeniom masy ciała u dzieci wpływ ma profilaktyka I, II, III fazy. Promocja zdrowego stylu życia, w tym aktywności fizycznej, w której uczestniczy cała rodzina jest niezwykle korzystne dla zdrowia, ale i dla utrzymania dobrych relacji miedzy rodzicami, a dzieckiem. Badania przesiewowe pozwalają zdiagnozować zaburzenie i podjąć odpowiednie kroki. Edukacja zdrowotna prowadzona przez pielęgniarki jest znaczącym elementem między innymi dzięki, któremu rodzice i opiekunowie uczą się jak być wsparciem dla dziecka z zaburzeniami masy ciała, ale także uwrażliwia rówieśników na problemy innych uczniów. Istotnie ważne jest, żeby na odrzucenie i brak akceptacji w szkole reagowali wszyscy: wychowawcy, nauczyciele, rodzice i opiekunowie oraz personel medyczny, ponieważ niedostrzeganie przejawów uprzedzeń służy rozwojowi dyskryminacji. 


\section{Bibliografia/ Bibliography:}

1. Tabak I., Oblacińska A., Jodłowska M. Psychospołeczne czynniki sprzyjające stosowaniu diety przez nastolatków z nadmiarem masy ciała. Medycyny Ogólna i Nauki o Zdrowiu. 2014;20,2:120-125.

2. Oblacińska A., Weker H. (red). Profilaktyka u dzieci i młodzieży. Wydawnictwo Help Med. Kraków 2008:12-23,86-98,151-164.

3. Woynarowska B.(red). Profilaktyka w pediatrii. Wydawnictwo Lekarskie PZWL. Warszawa 2008:207-210

4. Wolnicka K., Taraszewska A., Jaczewska-Schuetz J. Występowanie nadwagi, otyłości oraz niedoboru masy ciała wśród uczniów klas III szkół podstawowych z uwzględnieniem różnic regionalnych. Pracownia Żywienia Dzieci i Młodzieży, Zakład Żywienia i Dietetyki z Kliniką Chorób Metabolicznych i Gastroenterologii, Instytut Żywności i Żywienia w Warszawie. (https://journals.viamedica.pl/eoizpm/article/view/25934/20744 stan na dzień 26.04.2020r)

5. Kryska S. Stygmatyzacja dzieci otyłych jako przykład braku akceptacji rówieśniczej. Studia i prace pedagogiczne. 2014;(1):193-201.

6. Krajewska-Siuda E., Nowak A., Matusik P., Wypych-Ślusarska A., Małecka-Tendera E. Opinie młodzieży na temat otyłości w zależności od ich własnej masy ciała. Katedra i Klinika Pediatrii, Endokrynologii i Diabetologii Dziecięcej Śląskiego Uniwersytetu Medycznego w Katowicach Zakład Epidemiologii, Śląskiego Uniwersytetu Medycznego w Katowicach. (https://journals.viamedica.pl/eoizpm/article/view/26024/20834 stan na dzień 26.04.2020r)

7. Szulaczuk W., Skuzińska A. Dziecko z niepowodzeniami szkolnymi w grupie rówieśniczej. (http://www.sp1.info.elblag.pl/media/pliki/Dziecko_z_ niepowodzeniami_szkolnymi.pdf stan na dzień 27.04.2020 r.) 